


\section{RETHINKING EUROPEAN UNION FOREIGN POLICY}

Published in our centenary year

$\approx 2004 \leadsto$ MANCHESTER

UNIVERSITY PRESS 


\section{EUROPE}

already published

The formation of Croatian national identity

A centuries old dream

ALEX J. BELLAMY

Committee governance in the European Union

THOMAS CHRISTIANSEN AND EMIL KIRCHNER (EDS)

Theory and reform in the European Union, 2nd edition

DIMITRIS N. CHRYSSOCHOOU, MICHAEL J. TSINISIZELIS,

KOSTAS IFANTIS AND STELIOS STAVRIDIS

German policy-making and eastern enlargement of the EU during the Kohl era

Managing the agenda

STEPHEN D. COLLINS

The European Union and the Cyprus conflict

Modern conflict, postmodern union

THOMAS DIEZ

The time of European governance

MAGNUS EKENGREN

An introduction to post-Communist Bulgaria

Political, economic and social transformation

EMIL GIATZIDIS

The new Germany and migration in Europe

BARBARA MARSHALL

Turkey: facing a new millennium

Coping with intertwined conflicts

AMIKAM NACHMANI

The road to the European Union, volume 2

Estonia, Latvia and Lithuania

Vello PETTAi AND JAN ZEILONKa (EDS)

The road to the European Union, volume 1

The Czech and Slovak Republics

JACQUES RUPNIK AND JAN ZEILONKA (EDS)

Europe and civil society

Movement coalitions and European governance

CARLO RUZZA

Two tiers or two speeds?

The European security order and the enlargement of the European Union and NATO

JAMES SPERLING (ED)

Recasting the European order

Security architectures and economic cooperation

JAMES SPERLING AND EMIL KIRCHNER

The emerging Euro-Mediterranean system

DIMITRIS K. XENAKIS AND DIMITRIS N. CHRYSSOCHOOU 
Ben Tonra and Thomas Christiansen EDITORS

\section{RETHINKING \\ EUROPEAN UNION FOREIGN POLICY}

MANCHESTER UNIVERSIT Y PRESS

Manchester 
Copyright (C) Manchester University Press 2004

While copyright in the volume as a whole is vested in Manchester University Press, copyright in individual chapters belongs to their respective authors.

This electronic version has been made freely available under a Creative Commons (CC-BYNC-ND) licence, which permits non-commercial use, distribution and reproduction provided the author(s) and Manchester University Press are fully cited and no modifications or adaptations are made. Details of the licence can be viewed at https://creativecommons.org/licenses/by-nc-nd/3.0/

Published by Manchester University Press Altrincham Street, Manchester M1 7JA

www.manchesteruniversitypress.co.uk

British Library Cataloguing-in-Publication Data

A catalogue record for this book is available from the British Library

Library of Congress Cataloging-in-Publication Data applied for

ISBN 071906001 X hardback

0719060028 paperback

First published 2004

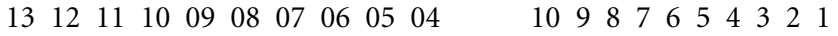

Typeset in Minion with Lithos

by Northern Phototypesetting Co Ltd, Bolton 